\title{
A DISCOURSE ANALYSIS OF SBY'S INTERNATIONAL SPEECH TEXT: A STUDY ON CRITICAL LINGUISTICS
}

\author{
Anggara Jatu Kusumawati \\ Gadjah Mada University
}

\begin{abstract}
President Susilo Bambang Yudhoyono (SBY) image building can be represented through many ways, one of them reflected on his international speeches. On this way, argumentation phases in the speeches can form social construct, self image, public opinion, new meaning and world-view. Based on critical linguistic point of view, word choice, sentence arrangement, and sentence pattern on speeches show a language expertise. This research aims at describing grammar used of SBY international speeches related with self image building.

This research uses critical linguistics approach proposed by Fowler (1979) via Young and Harrison (2004: 3) which focuses on two metafunctions of Systemic Functional Linguistics Halliday, ideational and textual function. The source of data are nine texts of SBY's international speech in the year of 2011 chosen based on some criteria; updated topics, variation of topics, and abundant data. Then, data are chosen, noted, and identified based on formulation of the problems. On data analysis, Norman Fairclough framework applied in analyzing the data. Based on limitation of Halliday's metafunction, only were two levels chosen; textual analysis and social practice analysis. Besides, relevant studies were done to get detail and complete explanation.

Based on data analysis, the result that can be emphasized is the grammar seen from word choice, clause and sentence element, figures of speech, pattern of clause change are means to convey new meaning based on who is the speaker and psychological effect shown to listeners. Thus, it can reveal the speaker purpose extensively and help to describe argumentative phase on speeches. Those three results of research are efforts to build SBY self image on language expertise. On this way, SBY can attract sympathy, therefore international cooperation can run smoothly.
\end{abstract}

Key words: international speeches discourse, self image, critical linguistic structure, text arrangement, grammar. 


\section{BACKGROUND OF THE PROBLEM}

Speech can be used as a tool to construct reality, self image, public opinion, new meaning of certain experiences. International speech which becomes the object of this research with a broad range of between developed and developing countries. As a country that is trying to get ahead, Indonesia needs support from other countries. The speech is a great tool to get international support. Such support can be created by having a trust from audiences (in and outside the country). In order to obtain a trust which is believed to be a truth or reality, language skills are very necessary in drawing up the text of the speech. Thus, the text of the international SBY speech is one form of language consisting of a set of sentences that have a sense of relationship with one another, then a lot of linguistic aspects contained in it.

Viewed in terms of Linguistics, word usage, sentence order, and sentence forms in speech are not viewed merely as technical matters of grammar or Linguistics, but the expression of ideology (Fowler via Eriyanto, 2009: 149). The expression is an attempt to form a general opinion, affirming and justifying his own side. Language usage is not neutral since it brings implications of a particular ideology. In fact, the President uses his speech to form a self-image which is proficient in using the language.

Language proficiency in an international speech text showed by president in several aspects. One of them is the use of grammar that describes how the words linked in intent and specific purpose. Word choice and the sentence formation have strongly influenced the meaning conveyed. In addition, 'aesthetic' form of language is also used into consideration in the sentence making process. This aims to add meaning or confirms assert a common nature an idea.

Language proficiency shown in the international speech text is extraordinary. The purpose and objective of speech are well delivered though with simple language but well-ordered. Through grammar, president SBY tries to perform self image as leader who is proficient using language. On this way, president convinces something as a truth or reality. Hence, this research aims to answer how the grammar is used in international speech text to form self-image based on critical linguistic perspective.

In relation with the language process as the major process of $C D A$ (Critical Discourse Analysis), linguistic criticism will be used for analyzing discourse 
practice shown in the text. This approach is done through theoretical and linguistic methodology. This is in line with the concept of Systemic Functional Linguistics $(S F L)$ proposed by Halliday. SFL is the method used to analyze text in terms of linguistics. This theoretical framework is one of the ways to understand language function and word choice produced to change meaning. The use of grammar which involves of words not only forms a sentence, but also sees meaning represented based on or outside the context of language (Young and Fitzgerald, 2006: 16).

Fowler (1979) in Young and Harrison (2004: 3) connects SFL and Critical Discourse Analysis emphasizing that ideology can be mediated linguistically. Metafunctional features is useful in critical analysis. For example, ideasional function of grammar transitivity, interpersonal function the grammar of modality, textual function which researchs transformation, nominalization, passivization, and classification of lexical patterns.

Moreover, Fowler (1981: 29-32) says that lingual units of language and control express and construct ideology. A text indirectly is an instrument controlling human behaviours. Lingual units in texts are shown in sentences. Syntactical construction analysis is needed to express ideology in the text. There are two construction prevalently appear, such as nominalization and passive voice. Those two forms dominates in the text. Nominalization is a transformational process to reduce clauses containing verbs and change into noun. The function of nominalization is to ease ideology codes to be constructed. This process helps relexicalization, new and special codes, and a new set of lexical terms. Passive voice in sentence consists of agent and patient that can make confusion 'who does what and to whom'. In passive form, someone tends to read a sentence from a beginning in which the position of the agent usually is. In the end, someone who has something done by another can be seen as the one who is responsible for what happened. This way the syntactic construction can reveal the ideology.

The grammar in speech text is well arranged to form a text on the basis of particular purpose. Grammar not only shows how a series of words trung together into a clause, but also be a means to indicate a particular meaning based on who the user is and the effect inflicted to the listener. Based on the speech texts discussed in this research, the speaker is a leader of a nation, and the texts are addressed in front of international audience. Therefore, the use of grammar is well considered based on the effect appeared. 
Based on the theory of $S F L$, Halliday suggests that the practice of grammar as a tool be communicated to the audience which consists of several important aspects, namely, aspect the choice of words and grammar. Thus, this research is developed based on the theory of Fowler; choice of word aspect, clause arrangement, and figure of speech. The third aspect is an additional finding because of the excessively uses of figure of speech.

\section{RESEARCH METHODOLOGY}

This discourse analysis on SBY's international speech text uses critical theory of Linguistics expressed by Fowler (1979) in Young and Harrison (2004: 3) which focuses on two functions of Halliday's SFL; ideational function and textual function. Therefore, this research aims at describing the grammar and its role in forming SBY self image in international speech text. This research consists of three phases, 1) collecting data, describing the method and technique used, 2) data analysis, describing process and data analysis, and 3) research results description.

Data source in this research is an English speech text addressed by President Susilo Bambang Yudhoyoo on international occasion in 2011 on April 8 at 'Fifteenth ASEAN Finance Ministers GCO Meeting'. This research is based on linguistic phenomenon. The phenomenon are observed first then chosen based on proper and certain limitation. Research population in this research is text of SBY's international speech. There are three criteria in choosing the population, first, up to date topic, the speech text addressed in 2011. The consideration is based on the recent topic that will be relevant with the recent international problems. Second, topic variation, this serves language variation and meaning in it. Third, abundant data, the text chosen is based on the abundant data both linguistic and nonlinguistic aspect in order to answer the formulation of the problem in this research. The speech text is from International Staff Assistant of President Dr. Yayan G. H. Mulyana delivered by email, so it fulfills data accurateness.

To understand deeply, the researcher observes the use of languange, then notes the relevant language use. The data is classified based on the formulation of the problem. The process of observing, noting, and data classification ease data analysis process.

The next phase is data analysis. Studying relevant literature helps to analyze the research data in getting detail and complete explanation. Based on critical 
discourse framework of Norman Fairclough, the analysis method consists of three levels, 1) textual level discussing form and content, 2) discourse practice level discussing the production socio-cognitive aspects and text interpretation, and 3) social practice level discussing different social organization (broader range). Only are two levels taken as objects of analysis, textual level and social practice level. This is in line with the main theory used in this research, critical linguistics, proposed by Roger Fowler that the analysis focuses on text that has relation with representation of self experience in social context or broader society. Hence, interview with the speaker creating discourse or one who has relation on it is not necessary. Data analysis is only based on elements served on text or known by the researcher or based on relevant theories, so it can answer the formulation of the problem. The discourse analysis framework can be shown below (Titscher, Mayer, Wodak, \& Vetter, 2009: 249).

\section{Figure 1. The Conceptual Framework of Norman Fairclough Critical Discourse Analysis.}

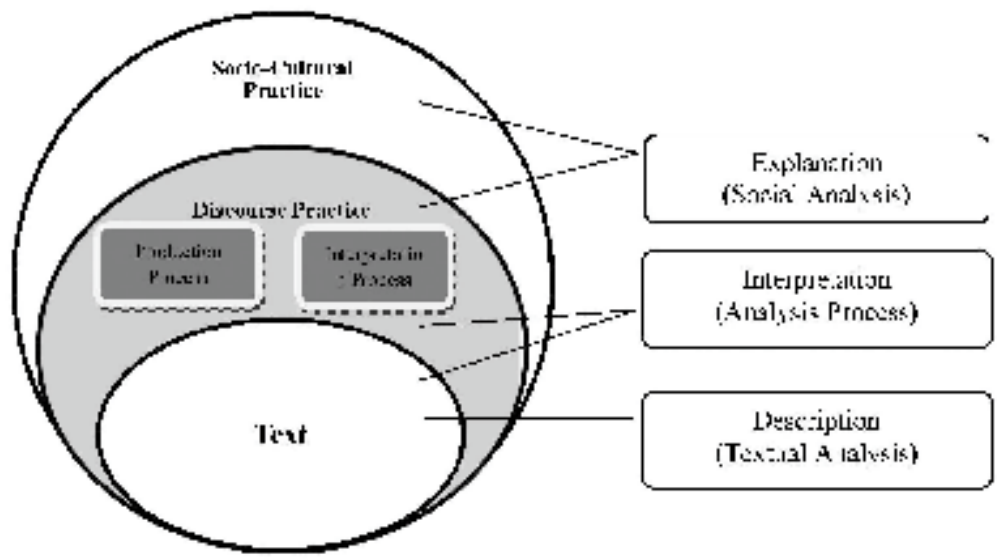




\section{Figure 2. The Conceptual Framework of Critical Discourse Framework Analysis in SBY's International Speech Text}

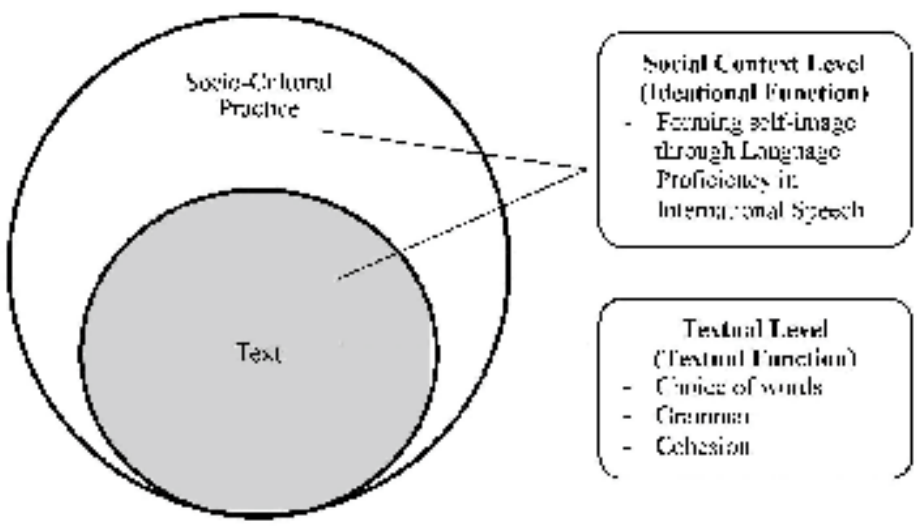

The third phase is describing the findings based on conceptual framework and formulation of the problem. The description is presented through words and relevant examples, so the information is accessible, detail and complete. This finding aims at describing the grammar of the text and its roles in forming SBY's selfimage.

\section{ANALYSIS}

\section{Choice of Words}

Accurate choice of words in the text of speech is important in expressing an idea or ideas. This is not simple thing. Mastery of choosing words greatly affects the purpose for which is about to be revealed. Choice of words should not be simple, nor too extravagant so that there is no implied meaning in it. Someone is called as a proficient in language is the man who is able to communicate with major vocabulary and can use it in a clear, effective and in accordance with the standard rules. This choice of word analysis consists of two parts; lexical pattern and critical discourse perspective.

\section{Lexical Pattern}

Form and meaning of words are fundamental in grammar. These will affect the sentence formed. Based on lexical pattern, there are two patterns will be discussed; lexical meaning and lexical pattern. 


\section{a. Lexical Meaning}

Accurateness choice of words is affected by lexical meaning. Based on the meaning, a word consists of denotative meaning and connotative meaning. Denotative meaning is a word or a group of words that directly and objectively refers to something outside the language (Keraf, 2009: 28). The use of denotative word helps readers or listeners to get direct meaning and no other interpretations. As in SBY's international speech text, it has many argumentations phases which are long and convincing the listeners, so there are also many denotative meanings in sentences. Below is example of the denotative meaning in order to explain a set of certain occasion.

... Let me briefly share with you what I mean, based on our current experience. Since 2007, the government of Indonesia has introduced an innovative credit scheme called "Credit for the People" (KUR Kredit Usaha Rakyat), which is executed through commercial banks, and 70\% of which is guaranteed by the Government. Annually, the Government of Indonesia guarantees increases capital of the guarantee companies the amount of two trillion rupiah (approximately 200 million US dollars), or guaranteeing 20 trillion rupiah of loans. This allows microenterprises lacking collaterals to access bank loans.

The KUR credit program has also been expanded to target micro entrepreneurs, in need of smaller loans of less than 20 million rupiah approximately more than 2000 US dollars. Remarkably, up to July 2010, more than three million small and medium enterprises have accessed this program. Of these, $96 \%$ are micro clients with an average loan size of four million rupiah, or more than 400 US dollars.

I am proud to mention, that this program has improved the status of approximately 400 thousand out of 4.1 million debtors, from unbankable to the entitled ones. More bankable persons mean more opportunity for development.

To complement financial inclusion program, the Indonesian Government has also developed other poverty reduction programs such as: cash support to the very poor, to compensate their decreasing purchasing power following the increase in oil price, and promoting "The National Program for Community Empowerment. "... 
Based on the data above, president gives an illustration of government experience in economy. It is innovative credit program namely "KUR-Kredit Usaha Rakyat". Denotatively, president gives an explanation when this program starts, a percentage guaranteed by government, an amount of loan given. Besides, there is an explanation the growth of credit program that achieves the enlargement target on micro entrepreneur. The last, the result of innovative credit program helps 400.000 entrepreneurs then the conclusion of the paragraph narrates the program "KUR" has also helped many entrepreneurs to develop. All choice words used in the narration have denotative meaning, which all things can be observed by senses and human ratio. There is no other interpretation appearing from the narration. This eases listeners to understand the explanation from the speaker.

Next, connotative shows positive impression and also represent speaker's tone. Connotative meaning is added to denotative meaning and can be a symbol of speaker's emotion or tone (Keraf, 2009: 29). The tone is a statement of agreement or disagreement, pleased or unpleased, polite or impolite, negative or positive, so the listeners will positively and emotionally be affected. The next is an example of the positive connotation word.

... Despite the pristine beaches and the many entertainment spots on this island, the meetings this week will surely drain your energy levels. To recharge, I encourage you to spend an extra few days, to go and explore other Indonesian remarkable sites and islands.

The word pristine gives a positive connotation meaning. The word pristine has denotation meaning original. The comparison of denotative meaning original and connotation meaning can be shown below.

(a) Despite the primitive beaches and the many entertainment spots on this island, the meetings this week will surely drain your energy levels.

(b) Despite the undeveloped beaches and the many entertainment spots on this island, the meetings this week will surely drain your energy levels.

(c) Despite the original beaches and the many entertainment spots on this island, the meetings this week will surely drain your energy levels.

(d) Despite the pristine beaches and the many entertainment spots on this island, the meetings this week will surely drain your energy levels. 
The word primitive and undeveloped have negative connotation illustrating ancient and less developed beaches. The word original has denotative meaning and neutral. Next, the word choice pristine gives positive impression showing original, clean, fresh beaches, so it is appropriate as a reference place to be visited. The use positive connotation can also alternate the use high language. The language is used by honorable and respectable person, also heard in front of reputable persons.

Based on the purpose, a proper choice of word both denotative and connotative meaning has its own function that gives clear explanations. The correct choice of words needs good language proficiency. Mistaken choice of word affects on wrong interpretation and bad impression. In relation with previous explanation, the choice of words delivered by President SBY is purposively well chosen.

\section{b. Lexical Structure}

There are some word semantic relations such as synonym, hyponym, and antonym. The examples of semantic relations found in SBY speech text can be shown as follow.

\section{Synonym}

Synonym derives from the word $s y n=$ same and onoma=name which means a word that has the same meanings (Keraf, 2009: 34). Despites, few words have the identical meaning, but this concept of synonym helps listeners to understand the speaker's explanation.

This is because there is a connection between the formers words. In addition, synonym helps the speaker to increase his vocabulary. The next are words having synonym meaning used together in sentence. The next are examples of synonym words used together in sentence.

... ASEAN can take the lead in resolving problems in our own backyard. ASEAN nations can serve as the "agent of change", that drives progress and development in many areas of cooperation within the region, be it financial cooperation, food security, energy security, inclusiveness, or equitable growth.

The word development and growth have similar meaning. The similarity is used for the same word environment. This is for clear meaning that the economic growth runs smoothly. 


\section{Hyponym}

Hyponym is a general-specific relation between two words or more. The specific word is called as hyponym (Keraf, 2009: 38). In the speech text of SBY, there is a specific hyponym that refers to related context. Below is an example of hyponym.

... This is of course no time to be complacent. Our economies are still facing many challenges. These are, among others: the continuing global imbalances, upward pressures on commodity prices, the rising price of oil, and the increasing severity and impact of natural disasters and climate changewhich in their own right affect the supply of our precious commodities. ...

The word many challenges is the general idea of some specific words, the continuing global imbalances, upward pressures on commodity prices, the rising price of oil, the increasing severity and impact of natural disasters and climate change. The general-specific words are related based on certain context. This specialty makes the sentence context exclusively shown through the speech text. A new concept is delivered to international audience on worldwide occasion.

The synonym and hyponym show word choice complexity. The more complex choice of words, the higher level of speaker's language proficiency. Therefore, the word choice of meaning and word structure determines speaker's purpose. In relation with language proficiency, appropriate choice of word gives a good impression to listeners.

\section{Critical Linguistic Perspective}

Based on critical linguistics point of view, the analysis focuses on language aspects. The use of grammar involving choice of words is not only viewed from sentence structure, but also meaning represented or realized based on nonlinguistics context (Young dan Fitzgerald, 2006: 16). Therefore, words structure, clause in sentence arranged to form new meaning. Fowler (1979) in Eriyanto (2009: 134) states four functions choice of words in sentence; classification, view limitation, discourse battle, and marginalization.

\section{a. Classification}

Reality shown in text speech is based on President SBY perspective. Choice of words chosen may limit and assess information experienced by the speaker. 
Exclude the factual one, reality presented by the President is a satisfying economic growth. Below is an example taken from the data shown the satisfying economic growth.

...In fact, emerging and developing countries in Asia have become important engines for global growth. The economies of ASEAN and East Asia registered robust growth, and provided the expansion that was helpful for the global growth....

The data above shows that President SBY classifies his government grows as global a growing machine. ASEAN economy and East Asia are listed in steady economy, and growth complement that help global growth. The listeners are guided to face reality classification from one side exposed by the President. The success of Indonesia from President SBY's perspective is the classification that limits the factual reality.

\section{b. Limitation of View}

The choice of word used in sentences limits the listeners view based on information exposed. That choice of word affects understanding to factual reality. The listeners are guided into speaker's understanding. As in the SBY international speech, there are realities exposed through choice of words that limit the listeners view. Below is an example containing choice of word as a limitation of view.

... At the same time, we also need to look closely on ASEAN's vision and our collective aspiration for our regional grouping.

We need to look at how do we develop strong national and regional economies with strong, sustainable, balanced and inclusive growth.

We need to move faster towards a true ASEAN Community by 2015. This means, among others, strengthening ASEAN institutional frameworks and mechanisms....

Based on the data above, the reality represented the listeners is limited on information stated. President states some actions that should be done by ASEAN. This emphasizes on the actions mentioned not the others. This limits the important actions for the good sake ofASEAN.

\section{c. Discourse Battle}

The international speech has argumentation phases that the speaker demands confession of truth by stating factual statement and justifying truth. The factual 
statement dan justifying truth are closed to the rality affecting listeners and at the end mutually belief are found. The choice of word is accepted as a truth. Below is an example of data containing argumentation, factual statement, and justifying truth.

\begin{tabular}{ll}
\hline \multicolumn{1}{c}{ Speech Text } & Detail \\
\hline $\begin{array}{l}\text { The increasing involvement of ASEAN in the international forums, } \\
\text { should be aimed not only to foster regional economic and }\end{array}$ & $\begin{array}{c}\text { Argumentation } \\
\text { financial growth, but also to encourage investment in the region, } \\
\text { and to improve our resilience against possible future crises. }\end{array}$ \\
& Statement \\
We will need to work closer together to manage the world & Support \\
economy, so that it can meet our needs, and also the global needs. & \\
Essentially, we are talking about regional and global partnerships. & \\
& \\
This effort is in fact, in line with the mandate given by the leaders & Support \\
to the ASEAN Finance Ministers, to sustain the recovery and & \\
restore growth. This can be done by way of implementing appropriate & \\
macro-economic policies, which is supported by structural reforms. & \\
We need to give a particular emphasis, on enhancing the stability & \\
of our financial markets. & \\
\hline
\end{tabular}

Argumentation focuses on an increasing involvement of ASEAN in international forum. This has purpose not only drumming up regional economy and financial growth, but also invites regional infestations, and increases courage to against future crisis. The support statements in the data are working at global economy, so it will fulfill the needs, and global needs. This is in line with a mandate proposed by ASEAN Financial Minister to continue economy recovery and growth. It can be done by implementing suitable macro-economy policies supported by forming restructuring process. As a result, this accomplishment gives certain emphasis to stabilize financial trades.

The reality shown in the argumentation is well arranged to convince the listeners to a conclusion, a truth. This is called as discourse battle, in which the listeners compare previous discourses as knowledge. The better factual statement and justifying truth, the weaker previous discourses, and at the end these can be convinced as a truth. 


\section{a. Marginalization}

Roger Fowler states the choice of words in forming sentence or proposition has certain meaning that is not neutral, and it can form public opinion. On speech, the speaker is the main actor in all achievements related to economic problems, environments, other problems. There is no eviction of other sides or parties although there is omission other actor in solving economic difficulty, environment problem, and other obstacles. At the level of choice of words, there is an analysis of happening and actors involved. There are three aspects in the analysis; happening, subject and object of the happening. The happening analysis is not only related with how words arranged, but also certain purpose that will be presented. Below is an example of omission of other actors. It seems that there is an only actor of the national or international programs.

... Since 2007, the government of Indonesia has introduced an innovative credit scheme called "Credit for the People" (KUR Kredit Usaha Rakyat), which is executed through commercial banks, and 70\% of which is guaranteed by the Government.

I am proud to mention, that this program has improved the status of approximately 400 thousand out of 4.1 million debtors, from unbankable to the entitled ones. More bankable persons mean more opportunity for development.

To complement financial inclusion program, the Indonesian Government has also developed other poverty reduction programs such as: cash support to the very poor, to compensate their decreasing purchasing power following the increase in oil price, and promoting "The National Program for Community Empowerment." ...

The data above states that Indonesian Government ruled by a president that successfully improving and increasing prosperity. The other actors who help the process are not stated. Poverty decrease is not a big problem which needs many helps from many parties. Funding that is used by the government is may be a loan of World Bank. Therefore, president emphasizes that he is the only one who succeeds solve prosperity problem.

Based on critical linguistics, the choice of words certainly affects the meaning and perception received by the listeners; they are classification, view limitation, discourse battle, and marginalization. Those functions show that the President 
expertise in choosing words in order to expose his leading success in Indonesia and ASEAN. This is a proof that a linguistic unit, word(s) in speech can be well arranged with certain purpose and brings big effects to listeners.

\section{Clause}

A clause is arranged from some aspects which the arrangement can be changed, exchanged, omitted, added, combined with other clauses and rearranged. The changes of sentence structure can change whole meaning (Halliday in Fowler, 1986: 151). The changes pattern of clause structure based on critical linguistics are transitivity, nominalization, and passivization. Below are the details of those three patterns.

\section{Transitivity}

Transitivity is a grammar unit that is used systematically to expose correlations between participants involved in situation of communication, action, condition or happening (Halliday via Fowler, 1986: 151). There are two transitivity patterns; transitive and intransitive. The detail and example of the transitivity can be shown as follow.

\section{a. Transitive}

Transitive pattern is a process focusing on what or who causes something and another part is affected. This pattern shows an action done by agent through a verb. Below are some examples of transitive patterns in the speech text and the detail.

\begin{tabular}{|c|c|c|c|c|c|}
\hline $\begin{array}{l}\text { Sirute } \\
2 M \text { T) }\end{array}$ & 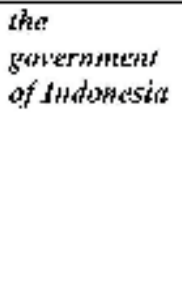 & $\begin{array}{l}\text { fors } \\
\text { introducedel }\end{array}$ & 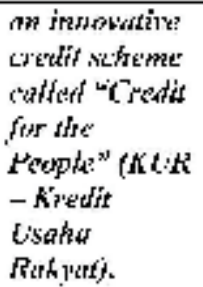 & 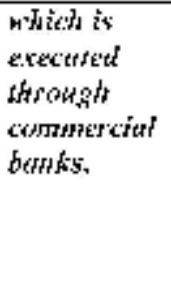 & 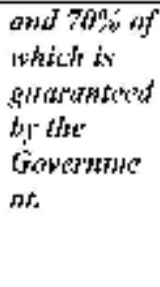 \\
\hline & & & How Head & $\begin{array}{l}\text { Arigective } \\
\text { cicluse i }\end{array}$ & 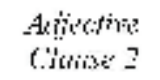 \\
\hline 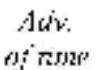 & Susterer & ratio & & O/ijeci & \\
\hline
\end{tabular}


The data above contains transitive sentence that shows subject as the agent, the government of Indonesia. The subject does an action has introduced an innovative credit program called "KUR-Kredit Usaha Rakyat". Sentence arrangement is in a form of transitive focusing on the agent who is the cause of an action. The result of the action is an effective program to solve poverty. This is important to show the success of the President and Indonesian Government in increasing prosperity. This action is presented in transitive sentence to focus on the agent as the cause of the action. Problems domestically and internationally appear, and it is hoped someone can help to solve the problem. Hence, the agent here is the one who is incredible then be a focus in transitive sentence, and also the effect of the action is problem solving.

\section{a. Intransitive}

Intransitive pattern shows an agent as the one who does the action without seeing the effect or the patient. This pattern focuses on the agent and the happening. Therefore, the absence of a patient has certain purpose, increasing focus on the agent. In this case, increasing focus in the SBY international speech text exposes a succesful leader in leading Indonesian government and also ASEAN countries. Below is an example of intransitive pattern in the speech and the detail.

... Today, the global economy is recovering, but the path to full recovery remains fraught with risks and vulnerability. ...

The sentence in the data above has intransitive pattern that focuses on a process happens in global economy. The global economy is an important point. That sentence is a warning to continue improving the previous global economic crisis. Besides, the word recover is repeated twice in that sentence with different part of speech. Hence, that sentence completely focuses on global economy and the recovery.

\section{Nominalization}

Nominalization is a process of a verb changing into a noun. It is possible that there is no subject and object in a sentence. Noun is a happening that does not need agent and patient. The process reduces agent and patient of a happening. Below is an example of nominalization on a word reform.

...In addition, through G20 forum, we managed to guide the reform process of International Financial Institutions. ... 
Data above shows nominalization process the reform process of International Financial Institutions. Nominal phrase has function as an object in the sentence. That is the result of lowering process from a clause. There is another focus of information occurred. Below is the lowering focus on the clause into nominal clause.

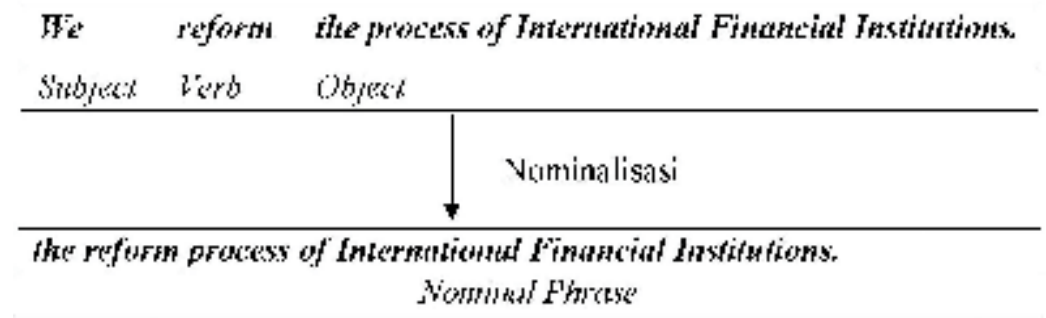

The nominalization process omits the role of subject and object of the action, so it lowers those two functions. On this process, the speaker gives more focus on the verb then changes it into noun. The lowering process happens on subject we and verb manage to guide.

\section{Passivization}

The other change of structures is the process of pasivization. It is a process of changing an active voice into a passive voice. The subject of a sentence follows verb and the object is on the beginning of sentence. This change changes the listener's focus. The listeners give more focus on the beginning of sentence. This raising focus affects and changes the meaning of sentence. The pasivization process can be shown on the sentence below.

... We will need to work closer together to manage the world economy, so that it can meet our needs, and also the global needs. Essentially, we are talking about regional and global partnerships. This effort is in fact, in line with the mandate given by the leaders to the ASEAN Finance Ministers, to sustain the recovery and restore growth. This can be done by way of implementing appropriate macro-economic policies, which is supported by structural reforms. We need to give a particular emphasis, on enhancing the stability of our financial markets. ... 
The data have focus varieties in describing an event. Two sentences on the beginning are active sentences focusing on the agent we that refers to 'ASEAN countries' and the happenings that refers to work and talk. The third and fourth sentence have more focus on the object of the sentence, so the sentence should be changed into passive voice. Below is the process of pasivization in the data.

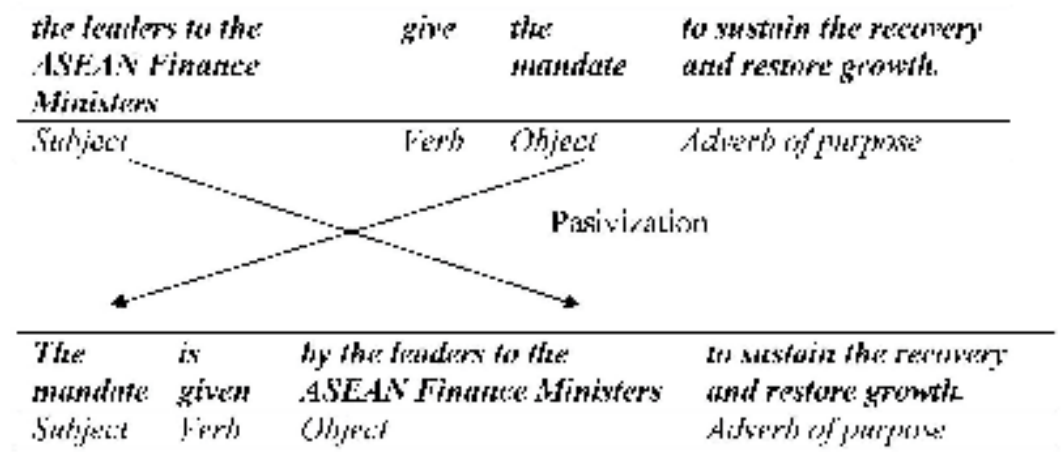

On the sentence above, there is a stress on the object of the sentence the mandate given by ASEAN Financial Minister, and then it moves to the beginning of sentence. This changes the focus of the sentence and also gives more stress on the agent. The next example of pasivization can be seen as follow.

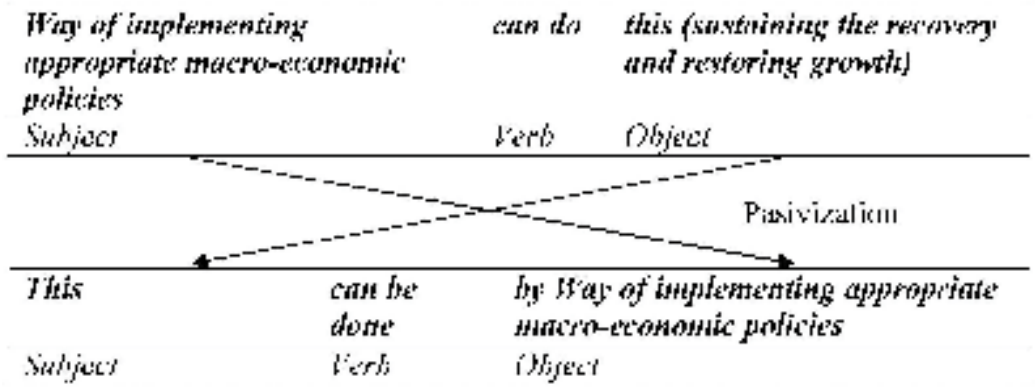

The purpose of mandate is sustaining the recovery and restoring growth getting more focus in the sentence. Therefore, the active voice changes into passive voice in which the object of sentence put on the beginning. The next sentence also uses passive voice to show the focus change of sentence. The object gets more focus put on the beginning. The next is also an example of passivization process. 


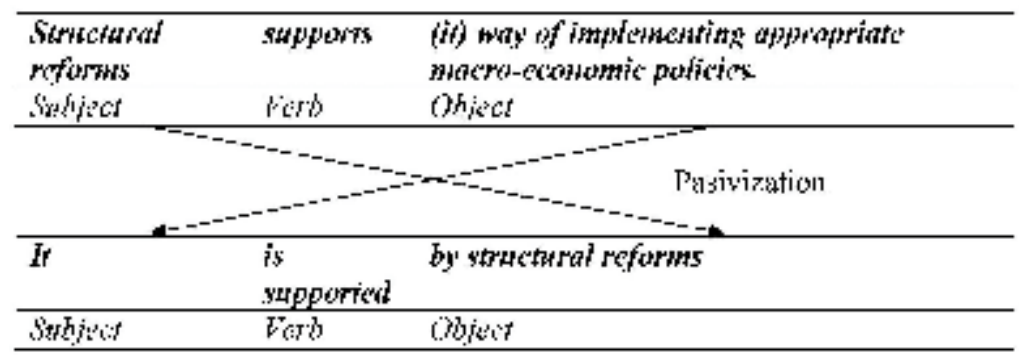

In active sentence, the subject structural reforms turns into lower focus than the object. The object of the sentence is way of implementing appropriate macroeconomic policies put on the beginning of the sentence. Automatically, the listeners focus more on the subject than the object. Then, the changes of sentence pattern are needed to show the speaker's intention.

Clause arrangement can be changed, exchanged, omitted, added, combined with other clauses and rearranged. The changes found in the SBY international speech are transitivity, nominalization, and pasivization. The three changes show the focus changes in sentence. The transitivity in a form of transitive sentence focuses on the agent and the effect done by the agent. Transitivity in a form of intransitive sentence focuses on the agent and the action done by the agent. Nominalization shows a happening that does not expose agent, patient, and the happening. Otherwise, pasivization is the focus change in which the one got more focus put on the beginning of the sentence. Instead changing the focus of sentence, those three patterns affects on the meaning.

\section{Figure of Speech}

In English grammar, figure of speech is used to communicate something beyond the concrete representation. This achieves different effect or adds certain sensation that cannot be attained in direct meaning. In other words, proficiency in adjusting listeners' emotion through figure of speech shows language proficiency. Besides, Keraf (2009: 113) states that an expression of thought through figure of speech can expose the speaker's characteristics and personality.

Based on the finding in speech text, President SBY uses figure of speech with accuracy and appropriateness in facing certain situations. Figure of speech is used to add certain effect and arouse listeners' emotion. On this way, the speaker tries to convince argumentation expressed as a factual truth. 
Figure of speech is seen from the direct or indirect meaning. If there is deviation from an ordinary and standard meaning, then it is called non-literal meaning or indirect meaning. Based on McCrimmon (1963: 152), a non-literal meaning is analogically used with another thing being introduced. One literal meaning is compared to a non-literal meaning. The analogy is done imaginatively to achieve more clarification and a psychology effect. McCrimmon (1963: 152) states that a figure of speech usually found are metaphor, personification, and synecdoche. Below are the three kind figures of speech in the SBY international speech.

\section{Metaphor}

Metaphor is an analogy or direct comparison of a concept with another concept. This is called as meaning transfer between referred words with the substitution. Below is an example found in the data the form of a noun phrase.

... In short, there is a sea of opportunity for the finance sector of ASEAN countries to innovate growth, both on the global economic front, as well as on the rural poverty front. ...

The phrase a sea of opportunity transfers meaning of the concept many opportunities with the concept sea containing countless water. Those two concepts exchanged into a sea of opportunity to describe countless opportunity. Another example of metaphor can be explained as follow.

... ASEAN can also serve as a building block for global growth, and also for a more effective global governance.

The data above contains a meaning transfer between the concept 'ASEAN' as a name of organization in South-East with the concept of 'building'. ASEAN can be visualized as a strong sympathetic organization that can support global growth and global domination. Those exchange concepts are called metaphor.

\section{Personification}

Personification is a figure of speech that treats animal, thing, happening, and abstract as human. Below is an example found in the data.

... All of us felt the pinch of the recent global financial crisis, which bled the world economy. We are fortunate to have passed the depth of this crisis, and avoided the worst case scenario of a global depression. 
Today, the global economy is recovering, but the path to full recovery remains fraught with risks and vulnerability. ...

A sentence above contains personification that treats a happening as a human doing an action. The happening is the financial crisis that can do the action pinch. The financial global crisis makes ASEAN countries are in economic troubles. It is illustrated by someone doing a pinch. The effect does not give serious injury, yet it gives discomfort. This is the illustration of financial crisis of ASEAN countries. It does not make serious effect, yet it gives some disadvantages. There are two things compared and illustrate the happening well.

\section{Synecdoche}

Based on Keraf (2009: 142), synecdoche is a figure of speech that uses a part of something to describe the whole (pars pro toto) or, in otherwise, uses the whole to expose a part of it (totum pro parte). Below is an example of synecdoche in the data.

... ASEAN can take the lead in resolving problems in our own backyard. ASEAN nations can serve as the "agent of change", that drives progress and development in many areas of cooperation within the region, be it financial cooperation, food security, energy security, inclusiveness, or equitable growth.

There is a sentence ASEAN can take the lead in resolving problems in our own backyard which has meaning deviation synecdoche pars pro toto. The deviation is the use a part of something to describe the whole. Representatives of ASEAN consist of few persons representing the countries they belong to.

Thus, the analogy deviation imaginatively uses metaphor, personification, synecdoche. Those deviations arouse psychological effects. This analogy is more effective to expose speaker's purpose when the meaning cannot be described well.

\section{CONCLUSION}

The use of grammar based on choice of word, clause arrangement, and figure of speech are the ways to expose certain meaning based on who is the speaker and the effect to the listeners. The changes patterns of clause and sentence can be changed, exchanged, omitted, added, combined with other clauses and rearranged. A stress 
on the part of sentence which can be in the form of lexical meaning changes, sentence focus changes, psychological effect affected from the use of grammar can expose speaker's intention well and help to express the argumentation phase in the speech. The proficiency in using grammar gives more impression and form self image to international audience.

\section{REFERENCES}

Eriyanto. 2009. Analisis Wacana. Yogyakarta: LKiS.

Fowler, R. (1981). Literature as Social Discourse: The Practice of Linguistics Criticism. London: Batsford Academic and Educational Ltd.

Fowler, R. (1986). Linguistic Criticism. New York: Oxford University Press.

Keraf, G. (2009). Diksi dan Gaya Bahasa. Jakarta: PT Gramedia Pustaka Umum.

Titscher, S., Mayer, M., Wodak, R., \& Vetter, E. (2009). Metode Analisis Teks dan Wacana. Yogyakarta: Pustaka Pelajar.

Young L. \& Harrison, C. (2004). Systemic Functional Linguistics and Critical Discourse Analysis. London: Continuum.

Young, L. \& Fitzgerald, B. (2006). The Power of Language: How discourse influences society. London: Equinox Publishing Ltd. 


\title{
Appendix. The Speech Text
}

\author{
DR. SUSILO BAMBANG YUDHOYONO \\ PRESIDENT OF THE REPUBLIC INDONESIA \\ $A T$ \\ FIFTEENTH ASEAN FINANCE MINISTERS GCO MEETING
}

JAKARTA, 8 APRIL 2011

Bismillahirrahmanir rahim,

Assalamu'alaikum warahmatullahi wabarakatuh,

Peace be upon us,

Salam sejahtera untuk kita semua.

Om Swastiastu,

Dr. Surin Pitsuwan, Secretary General of ASEAN,

Distinguished Ministers of Finance,

Distinguished Central Bank Governors,

Prof. Haruhiko Kuroda [:haru-hiko kur-roda], President of the Asian Development Bank,

Dr. Sri Mulyani Indrawati / Managing Director of the World Bank for the East Asia Pacific, Latin America, Carribean, Middle East, and North Africa,

Prof. Naoyuki Shinohara [:nao-yuki shi-no-hara], Deputy Managing Director of the International Monetary Fund

General I Made Mangku Pastika, Governor of Bali

Distinguished Participants,

Ladies and Gentlemen,

I am very pleased for this opportunity, to address the ASEAN Finance Ministers meeting here in Bali. To all the Finance Ministers and Central Bank Governors who are here today, I bid you a warm welcome to Indonesia.

Indonesia is honored to be the chair of ASEAN this year, and as we move forward, certainly finance cooperation is an area that has become increasingly urgent. We need to work together to strengthen regional financial resilience, which would advance the cause of the ASEAN Economic Community.

All of us felt the pinch of the recent global financial crisis, which bled the world 
economy. We are fortunate to have passed the depth of this crisis, and avoided the worst case scenario of a global depression. Today, the global economy is recovering, but the path to full recovery remains fraught with risks and vulnerability.

One important lesson from that global financial crisis was that countries needed to act fast, and to act together. This is precisely what the G20 did by working together to reform the financial architecture, prevent protectionism and aiming for a strong, sustainable, balanced global economic growth.

But even as the worst is behind us, some developed countries are still struggling to fix domestic economic challenges, and regain the growth momentum. This is a picture that is likely to continue in the short-term. In contrast, emerging and developing economies have led global economic recovery with positive economic growth.

In Asia, after a rigorous restructuring of its financial architecture since 1998, the region has become more resilient to global shocks.

In fact, emerging and developing countries in Asia have become important engines for global growth. The economies of ASEAN and East Asia registered robust growth, and provided the expansion that was helpful for the global growth.

This is of course no time to be complacen. Our economies are still facing many challenges. These are, among others : the continuing global imbalances, upward pressures on commodity prices, the rising price of oil, and the increasing severity and impact of natural disasters and climate changewhich in their own right affect the supply of our precious commodities.

Indeed, the recent global financial crisis and the recent commodity price increases, amplify the urgency for both policy coordination and global surveillance capacity building. Those challenges pose major threats to the global economic recovery, food and energy security, and achieving Millennium Development Goals.

While this situation is not newwe had it in 2008it warrants our collective efforts to lessen its adverse effect.

ASEAN should therefore be better prepared, in responding to this challenge. The increasing linkage of ASEAN to the global economy has enhanced the potential spillover from external shocks into our region.

The recent financial crisis has also taught us that global problems can be effectively addressed through, three separate but inter-connected policy actions: First, strong and prudent policies of individual countries, 
Second, coordinated regional responses, and Third, globally coordinated policy measures.

In the face of these realities, I urge our ASEAN colleagues and partner economies to enhance our strategy, and renew our commitments towards a more sustainable growth and stability within our region. ASEAN needs to be more adaptive and innovative.

On top of this, we in ASEAN must strengthen our framework, and become part of solutions to emerging global issues.

There are a number of questions that we should consider:

- How much have we done, to mitigate the potential impact of future financial crisis?

- How far have we come, in ensuring the security of our food and energy supply? And

- How much have we done collectively and individually, in responding to the challenge of climate change?

Answers to these questions, along with our own agenda for improving regional prosperity and growth, should be an important part of this meeting's discussions. At the same time, we also need to look closely on ASEAN's vision and our collective aspiration for our regional grouping.

We need to look at how do we develop strong national and regional economies with strong, sustainable, balanced and inclusive growth.

We need to move faster towards a true ASEAN Community by 2015. This means, among others, strengthening ASEAN institutional frameworks and mechanisms. We need to improve the quality of life of all ASEAN peoples. This is not just about higher living standards, but also about inclusiveness, through ensuring better access to public services, social safety nets, Small and Medium Enterprises (SMEs) development and financial inclusion schemes. It is also about ensuring better transparency and accountability, as well as ensuring an increased sense of security. Indeed, it is about bringing ASEAN to the people.

To realize this vision, there are three key priorities for ASEAN in 2011 and beyond. The first priority is ensuring significant progress and implementation of ASEAN community. For ASEAN Finance Ministers, this implies building on progress in financial services liberalization, capital market development and management of capitalflows.

This also means continued cooperation in customs initiatives, especially on the strategic plan for customs development, and the implementation of the ASEAN 
Single Window. Another challenge is to address any tax related impediments to integration, and ensure that the regional dialog on this issue will produce concrete recommendations and action.

The second priority is that, ASEAN needs to be more cohesive and competitive, to maintain its role as a driver for East Asia wide regionalism and architectur. In this context, post East Asian financial crisis of 1997 and 1998, Finance Ministers and Central Bank Governors have already put in place an ASEAN plus Three mechanism on macro economic policy coordination and surveillance, bilateral swap agreements, and a regional reserves pooling scheme under the Chiang Mai Initiative.

Finance Ministers and Central Bank Governors need to continue these regional efforts, to ensure that these schemes can be operational and implemented, and continue to be linked to international schemes.

Don't wait for the next financial crisis.

And the third priority is, for ASEAN to contribute to the global agreements and governance. Hence, I believe that we in ASEAN should strengthen our engagement with emerging global forums, such as the G20.

As a premier forum for global economic cooperation, the G20 has been able to provide collective responses and initiatives, to mitigate impacts of the latest financial crisis, as well as to build confidence towards global economic recovery. In addition, through G20 forum, we managed to guide the reform process of International Financial Institutions.

The increasing involvement of ASEAN in the international forums, should be aimed not only to foster regional economic and financial growth, but also to encourage investment in the region, and to improve our resilience against possible future crises.

We will need to work closer together to manage the world economy, so that it can meet our needs, and also the global needs. Essentially, we are talking about regional and global partnerships.

This effort is in fact, in line with the mandate given by the leaders to the ASEAN Finance Ministers, to sustain the recovery and restore growth. This can be done by way of implementing appropriate macro-economic policies, which is supported by structural reforms. We need to give a particular emphasis, on enhancing the stability of our financial markets.

We need to ensure that, our discussions will contribute to sustaining the global recovery in a post-crisis world. Moreover, we also need to ensure they will lead to 
the prospects for, an effective economic policy cooperation and coordination.

These are all momentous challenges for all of us, but we are up to meet them in a variety of ways.

ASEAN can take the lead in resolving problems in our own backyard. ASEAN nations can serve as the "agent of change", that drives progress and development in many areas of cooperation within the region, be it financial cooperation, food security, energy security, inclusiveness, or equitable growth.

ASEAN can also serve as a building block for global growth, and also for a more effective global governance.

Without the growth of dynamic regionalism in all parts of the world, there can be no globalism. This is why the key theme for ASEAN this year is, "ASEAN Community in a Global Community of Nations".

Distinguished Ministers, Ladies and Gentlemen,

Let me now touch on the significance of finance cooperation for the realization of the ASEANEconomic Community, an important pillar of the ASEANCommunity. Financial cooperation must touch on the issue of development, in particular when addressing the development gap between and within ASEAN economies. If we do not deal with this issue, then we run the risk of a two or even three-tier ASEAN. We therefore need to focus our structural policies and reforms, as well as developing economic corridors, to enhance national and regional connectivity and regional infra-structure development.

I am pleased that there is already an ASEAN Connectivity Master Plan, and I do hope that the plan will ensure not just land-based regional connectivity, but also maritime-based regional connectivity.

On our part, Indonesia is currently finalizing our own Master Plan for accelerating economic development and economic corridors. There will be six economic corridors in various regions of Indonesia, and in each corridors there will be growth areas. The vision of the masterplan is for Indonesia to be locally integrated and globally connected.

Progress is also visible in the implementation of the ASEAN Infrastructure Fund, with a view to narrowing the infrastructure development gaps in ASEAN. We must continue our efforts to increase the capacity of the fund, to meet pressing development demands in the region. 
I am pleased to note that since 2003, our cooperative actions in the financial sector have led to notable gains in the areas of financial services liberalization, capital market development, and capital account liberalization.

The ultimate goal of our cooperation, including in the finance sector, is to promote greater stability and prosperity of the ASEAN peoples.

I therefore believe that our collective efforts should contribute to our ability in addressing povertyone of the most pressing issues in the region.

The situation cannot be ignored: 1.4 billion people of the world population are still living with less than 1.25 US dollars per day, with around 118 million of them living in ASEAN countries.

Thus, we need financial inclusion for all of our ASEAN citizens. People living in poverty, usually do not have affordable access to financial services such as savings, loans, and transfer payment and insurance.

To lift our population out of poverty, we must provide affordable financial services. With broadened access, our population, including those living in poverty, can unlock financial and small business opportunities. These opportunities will, in turn, improve their well-being. Ultimately, this will reduce poverty and inequality. Through greater inclusion and participation of people from all levels of economy in society, we may foster greater ideas and innovation. We can promote ASEAN as, an even more people-centered organization than before.

Financial inclusion that addresses poverty must be innovative. It must not be business as usual, like regular financial services.

Let me briefly share with you what I mean, based on our current experience.

Since 2007, the government of Indonesia has introduced an innovative credit scheme called "Credit for the People" (KUR Kredit Usaha Rakyat), which is executed through commercial banks, and 70\% of which is guaranteed by the Government. Annually, the Government of Indonesia guarantees increases capital of the guarantee companies the amount of two trillion rupiah (approximately 200 million US dollars), or guaranteeing 20 trillion rupiah of loans. This allows microenterprises lacking collaterals to access bank loans.

The KUR credit program has also been expanded to target micro entrepreneurs, in need of smaller loans ofless than 20 million rupiah approximatelymore than 2000 US dollars. Remarkably, up to July 2010, more than three million small and medium enterprises have accessed this program. Of these, $96 \%$ are micro clients with an average loan size of four million rupiah, or more than 400 US dollars. 
I am proud to mention, that this program has improved the status of approximately 400 thousand out of 4.1 million debtors, from unbankable to the entitled ones. More bankable persons mean more opportunity for development.

To complement financial inclusion program, the Indonesian Government has also developed other poverty reduction programs such as: cash support to the very poor, to compensate their decreasing purchasing power following the increase in oil price, and promoting "The National Program for Community Empowerment." In short, there is a sea of opportunity for the finance sector of ASEAN countries to innovate growth, both on the global economic front, as well as on the rural poverty front.

No matter what is the level of development, each ASEAN economy has a stake in the success of the other. Our common future and shared interests bind us together like no other time before.

Distinguished Ministers,

Ladies and Gentlemen,

Before I conclude, I would like to wish you all productive deliberations.

I encourage you to delve into matters, critical to the advancement of finance cooperation within ASEAN. I encourage you to come up with tangible steps, towards building a strong and sustainable ASEAN Economic Community.

I also wish to thank the Asian Development Bank, The World Bank, the IMF and other international organizations for their continued support in the development of our region. I hope that this outstanding partnership will flourish further.

Despite the pristine beaches and the many entertainment spots on this island, the meetings this week will surely drain your energy levels. To recharge, I encourage you to spend an extra few days, to go and explore other Indonesian remarkable sites and islands.

And, finally, by saying Bismillahirrahmanir-rahim, I declare The Fifteenth ASEAN Finance Ministers' Meeting open.

Thankyou.

Wassalamu'alaikum warahmatullahi wabarakatuh.

Om Santhi, Santhi, Santhi Om 